\title{
The Effect of the Prevalence of Covid-19 on Arbitrary Use of Antibiotics
}

\author{
Mohammad Hossein Heydargoy ${ }^{1 *}$
}

1. Department of Microbiology, college of Basic Sciences, Shahre-e-Qods Branch, Islamic Azad University, Tehran, Iran

\section{ABSTRACT}

Background: Pathogens' resistance to antibiotics is one of the major problems in Iran and worldwide, which has caused the healthcare system to face many problems dealing with infectious agents. Following the prevalence of Covid-19, people with mild symptoms have avoided seeking medical attention while preferring self-medication. This has exacerbated the crisis of antibiotic resistance. Here we aimed to investigate the effect of the prevalence of Covid-19 on the arbitrary use of antibiotics.

Materials \& Methods: The data gathering tool was a researcher-made questionnaire. The study's target population was the servants of the holy shrine of Fatima Masumeh (PBUH) and members of Vanak Park Complex located in Tehran, Iran. A total of 168 people participated in this research and the results were summarized and presented as percentages and graphs.

Results \& Conclusion: $20.8 \%$ of people used antibiotics during the outbreak of Covid-19, of which $20 \%$ said that the outbreak of Covid-19 and quarantine prevented them from going to medical centers and self-medicating. In this case, it can be concluded that fear of coronavirus disease has affected the rate of referrals to medical centers and the intensification of self-medication and overuse of antibiotics, and finally the crisis of antibiotic resistance.

Keywords: Drug resistance, Resistance to antimicrobial drugs, Antibiotics, Coronavirus, Covid-19

\begin{tabular}{|c|c|c|c|c|}
\hline \multicolumn{3}{|c|}{ Received: 2020/07/08; } & Accepted: 2020/08/10; & Published Online: 2020/08/14 \\
\hline \multicolumn{2}{|c|}{ Corresponding Information: } & $\begin{array}{l}\text { Mohammad Hoss } \\
\text { Email: heydargoyC }\end{array}$ & $\begin{array}{l}\text { ydargoy, Department of Micro } \\
\text { au.ac.ir }\end{array}$ & gy, Shahr-e Ghods Branch, Azad Islamic University, Tehran, Iran. \\
\hline (c) (1) (9) & $\begin{array}{l}\text { Copyright } \odot 202 \\
\text { permits copy and }\end{array}$ & $\begin{array}{l}\text { This is an original open } \\
\text { redistribution of the mat }\end{array}$ & $\begin{array}{l}\text { irticle distributed under the terms of } \\
\text { in noncommercial usages with prope }\end{array}$ & $\begin{array}{l}\text { reative Commons Attribution-noncommercial } 4.0 \text { International License which } \\
\text { tion. }\end{array}$ \\
\hline
\end{tabular}

Use your device to scan and read the article online

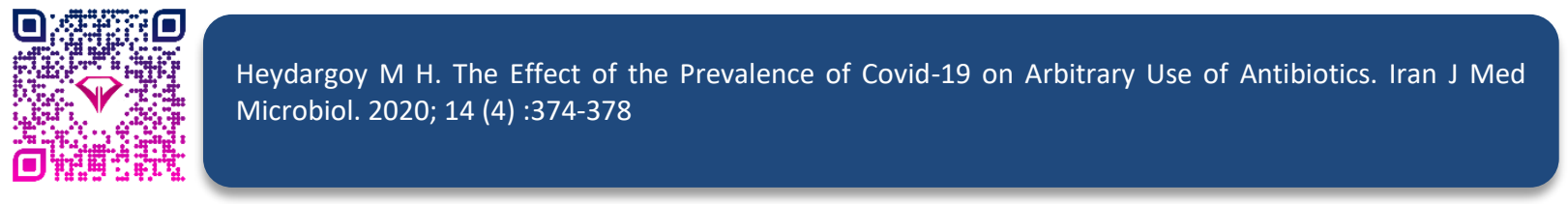

Download citation: BibTeX | RIS | EndNote | Medlars | ProCite | Reference Manager | RefWorks

Send citation to: $8 \underline{\text { Mendeley }} \bar{Z}$ zotero $\mathbb{H}_{\text {RefWorks }}$

\section{Introduction}

From the past decades until today, scientists have made great efforts to find various methods and drugs against microbes, but the resistance of pathogens to antibiotics has made it hard for the healthcare system to fight against them. Antibiotic resistance is a major crisis that has not been addressed and requires prompt action (1). Drug resistance means reducing the effectiveness of a drug in treating a disease caused by factors such as bacteria, parasites, viruses, fungi, and even cancer cells (2). Medication is an essential part of treatment (3). However, this does not mean that taking medication will have positive effects in any way. Medications can be both beneficial and healththreatening. Improper use of drugs due to lack of awareness can be dangerous (4). Statistical studies show that the amount of drug prescribed does not match the amount used; this indicates the abuse of the drug (5). One of the factors affecting the abuse of drugs is buying over-thecounter antibiotics in order to keep them at home. Sharing drugs with other people and prescribing drugs more than needed for patients is another factor playing an essential role in the misuse of antibiotics (6-9).

Iran is one of the largest consumers of antibiotics in the world due to the false culture of self-medication. Also, studies have shown that the amount of prescription drugs, especially by general practitioners, is too much, which leads to the storage of drugs at home and, eventually, the overuse of it. Misuse of drugs is also a significant problem in the world $(5,10)$. 
In this study, the use of antibiotics during Covid-19 onset was assessed using a questionnaire to determine if the prevalence of coronavirus disease has affected the use of antibiotics.

\section{Materials and Methods}

In this short article, an online questionnaire was designed that included questions about demographic characteristics and antibiotic use and awareness of the side effects of the arbitrary use of antibiotics. It was then posted on social networks used by the servants of the holy shrine of Fatima Masoumeh (PBUH) located in the holy city of Qom, Iran, as well as members of the Vanak Park Complex located in Tehran, Iran. The results were concluded as percentages and graphs. In order to control the answers, two questions were used in the questionnaire. For instance, a question asked, Did you take antibiotics without the doctor's prescription before the coronavirus outbreak?

Furthermore, to confirm the accuracy of the answers, there was another question asked, Have you taken antibiotics without a prescription due to the prevalence of coronavirus and the inability to go to medical centers?

If the person in question answers that he/she misused antibiotics before the corona outbreak period and in answer to the next question states that the abuse of antibiotics was due to the corona outbreak period, the answers will be inconsistently determining whether this individual was either self-medicating before. To elevate the eligibility of the answers, assuming that the study's target is all Muslims, we told them that if they fill in the questionnaire accidentally or without honesty, it will cause an error in the results of the research, and Sharia forbids this.

\section{Results \& Discussion}

During ten days, 168 people filled out a questionnaire, which included 152 servants of the holy shrine of Fatima Masoumeh (PBUH) and 16 members of Vanak Park Complex. Of these, $83.3 \%$ were female, and $16.7 \%$ were male. The age range of participants in this study was calculated from 15 to 67 years. Of these, $100 \%$ followed at least one of the recommendations, including wearing a mask, using gloves, and observing social distance.

Of the participants, $32.7 \%$ said they bought antibiotics just for home storage, and $38.1 \%$ of the participants used antibiotics without a doctor's prescription before the outbreak of Covid-19. In comparison, $20.8 \%$ of the participants used antibiotics during the outbreak of the participants, of whom $20 \%$ stated that the outbreak of Covid-19 and quarantine prevented them from seeking medical treatment, and as a result they preferred self-medication. In this case, it can be concluded that the epidemic of coronavirus in Iran has increased the use of antibiotics. Due to the fear of leaving home and going to crowded places, especially medical centers that may be affected by a coronavirus, people stay at home and tend self-medication.

It is suggested that medical organizations and authorities reduce the phenomenon of self-medication, and face-to-face visits during virus outbreaks, by expanding virtual consultation systems with physicians and reducing the cost of such services, as well as introducing and teaching the use of this tool.

\section{Acknowledgment}

The author would like to thank Ms. Fariba Asadpour Kofi, the caretaker of the Sisters of the Holy Shrine Unit of Fatima Masoumeh (PBUH), and Mr. Morteza Heydargoy, members of the Board of Trustees of Vanak Park Complex. They have contributed significantly to the research by sending and collecting questionnaires.

\section{Conflict of Interest}

The authors declared no conflict of interest. 


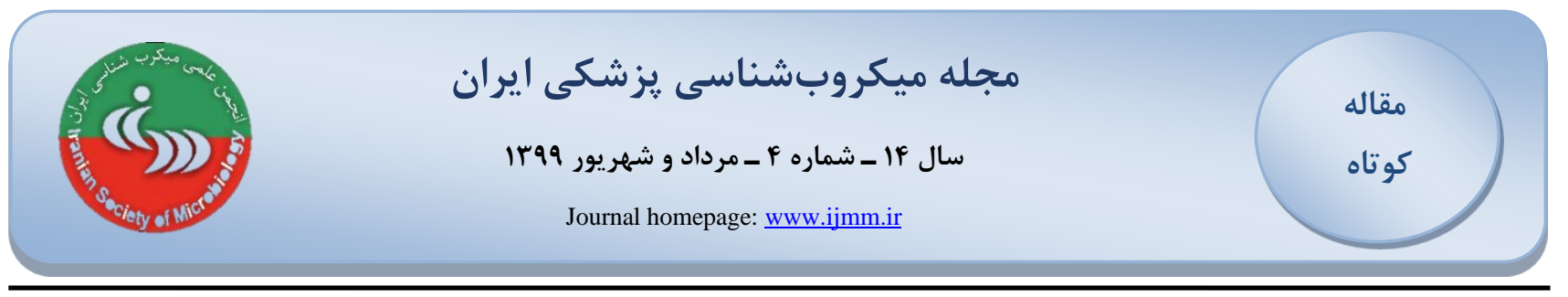

\section{بررسى تأثير شيوع بيمارى كرونا بر مصرف بعرويه آنتىبيوتيك}

\section{محمدحسين حيدر}

'. رَروه ميكروبيولوزى، دانشكده علوم پايه، واحد شهر قدس، دانشَاه آزاد اسلامى، تهران، ايران

\begin{tabular}{|c|c|}
\hline جـكيله & اطلاعات مقاله \\
\hline 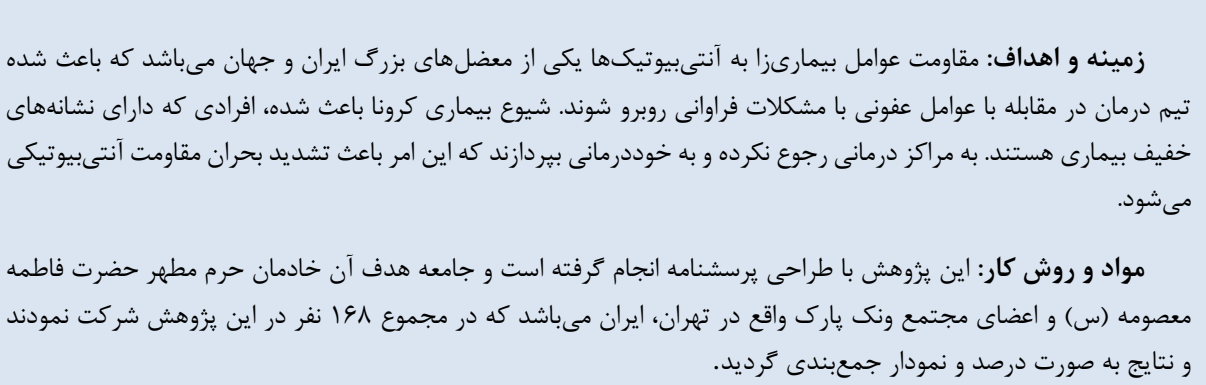 & 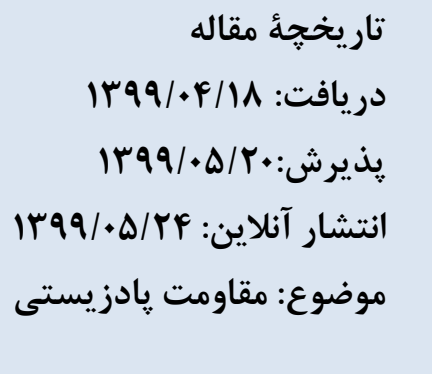 \\
\hline 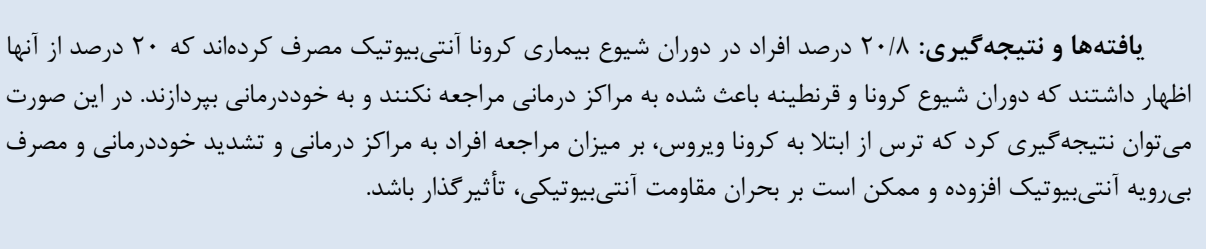 & 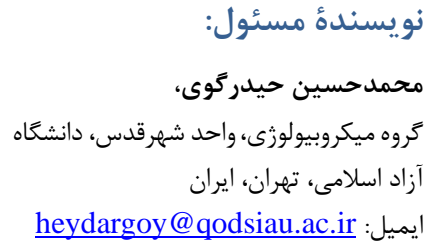 \\
\hline كليدوازهها: مقاومت دارويى، مقاومت به داروهاى ضد ميكروبى، آنتىبيوتيك، كرونا ويروس، كوويد-19. & \\
\hline
\end{tabular}

مقلدمه

همخوانى ندارد و اين امر نشاندهنده مصرف خودسرانه دارو مىباشد. (ه) از عوامل مؤثر در مصرف خودسرانه دارو خريد بدون نسخه آنتىبيوتيك به منظور نكمهارى دارو در خانه مىباشد كه يكى از عوامل

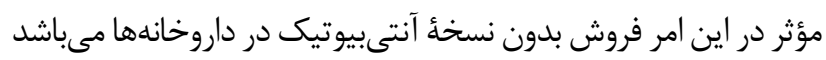
و همجنين تقسيم داروهاى تجويزشده يك فرد به اطرافيان و همجنين

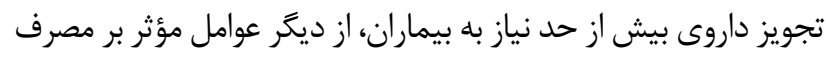

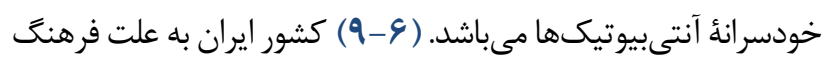

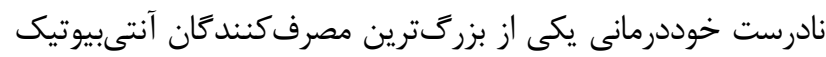

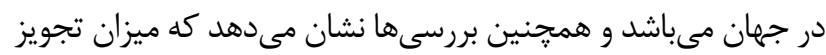
داروها به خصوص توسط يزشكهاى عمومى بيش از اندازه مورد نياز

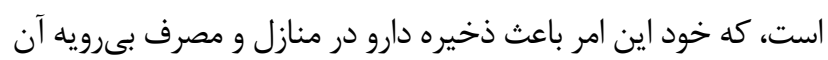
به منظور خوددرمانى مىشود. همجنين مصرف نادرست داروها يك معضل بزرگ در جهان محسوب مىشود. ( ه, • () در طى اين تحقيق،

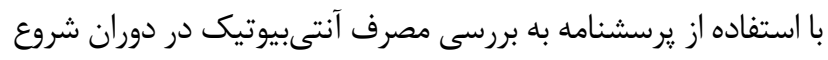

از دهdهاى گذشته تا به امروز دانشمندان تلاشهاى فراوانى براى به دست آوردن روشها و داروهاى مختلف برعليه ميكروبها

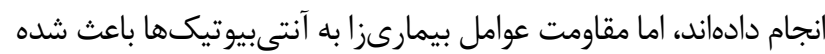
تا سيستم درمانى در تنگَنا قرار بخيرد. مقاومت آنتىبيوتيكى يك بحران بزرگ مىباشد كه موردتوجه قرار نخرفته است و نيازمند رسيدگى و اقدام سريع مىباشد. (1) مقاومت دارويى به معنى كاهش تأثير يك دارو در درمان يك بيمارى مىباشد كه توسط عواملى جون باكترىها، انكل ها، ويروسها، قارجها و حتى سلولهاى سرطانى ايجاد مىشود. (Y) مصرف دارو يك جزء مهرم از درمان مىباشد. ( (؟) اما اين بدين معنى نيست كه مصرف داروها به هر نحوى آثار مثبتى در بيى خواهد داشت. داروها مىتوانند مانند تيغى دو لبه هم مفيد باشند و هم باعث تهديد سلامت شوند. مصرف نادرست داروها كه ناشى از عدم

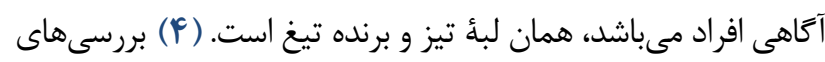
آمارى نشان مىدهد كه ميزان تجويز دارو با ميزان مصرف آن 
درصد افراد حداقل به يكى از توصيهها شامل: استفاده از ماسك،

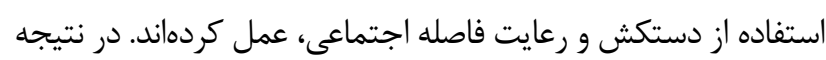

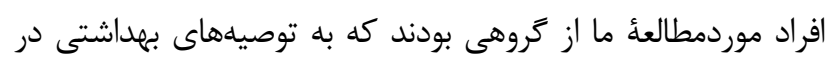

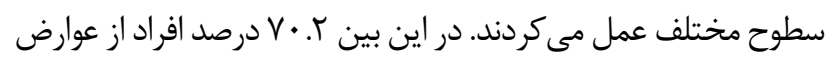

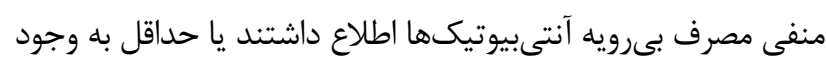
اين عوارض واقف بودند.

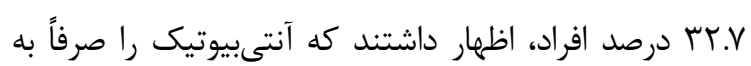

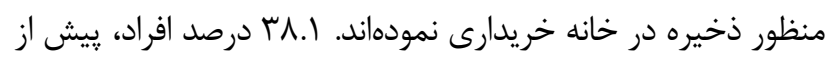

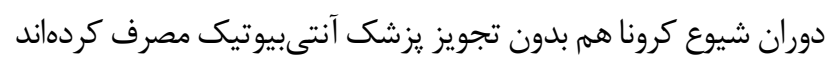

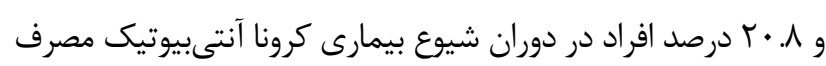

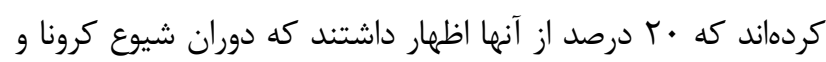

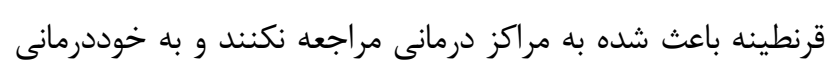

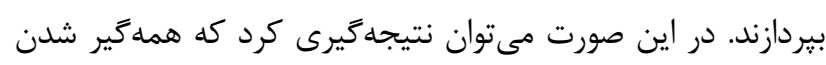

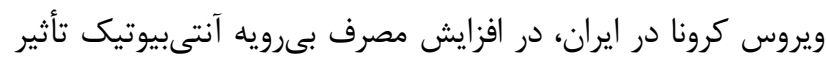

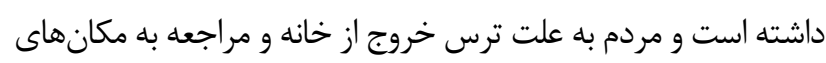

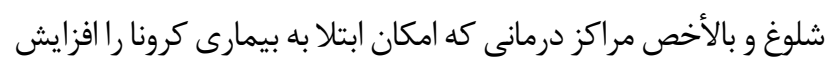

$$
\text { مى دهد، كَرايشى به خوددرمانى دارند. }
$$

بيشنهاد مىشود كه سازمانها و مراجع درمانى، با كسترش

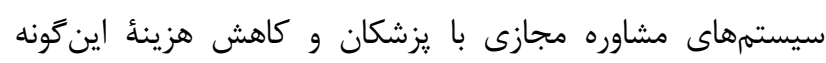

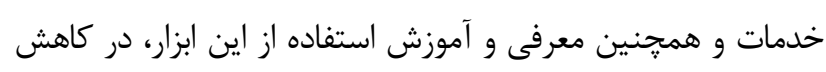

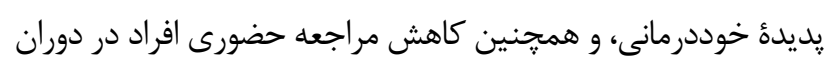
شيوع ويروس كرونا، بكوشند.

\section{سياسگز ارى}

تشكر مىكنم از سركار خانم فريبا اسديور كوفى خادم

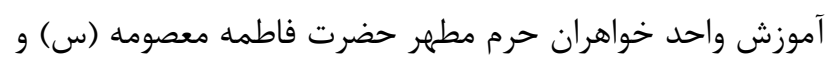

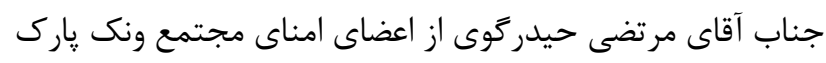

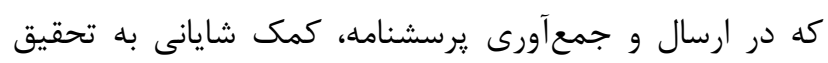
نمودهاند.

\section{تعارض در منافع}

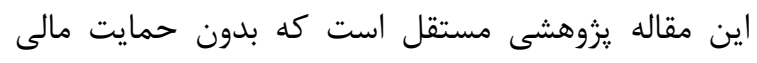

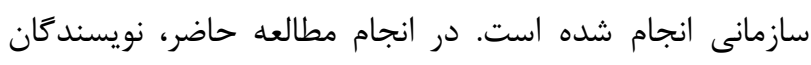
هيج كونه تضاد منافعى نداشتهاند.
كرونا يرداخت شده است. تا مشخص شود كه آيا شيوع بيمارى كرونا

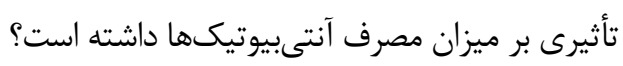

\section{روش يخوهش}

در اين مطالعه كوتاه، برسشنامةُ آنلاين طراحى شد كه شامل

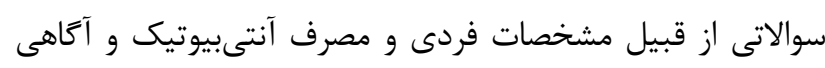

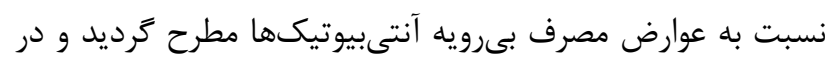

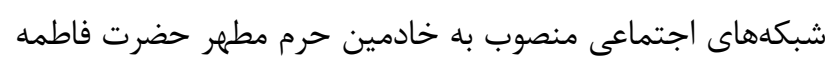

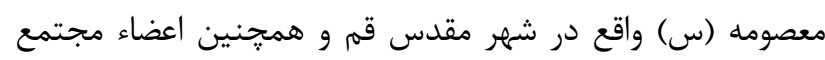

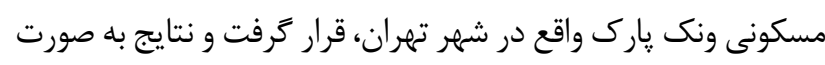

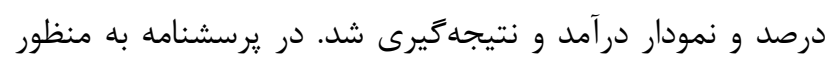

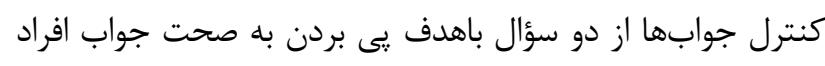

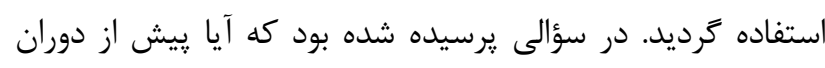

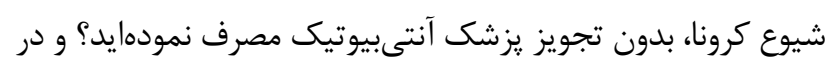

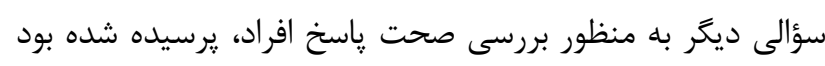

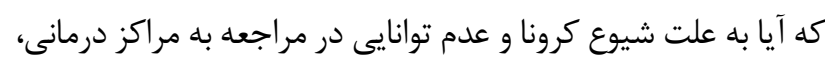

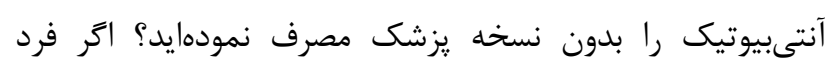

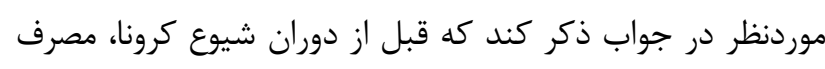

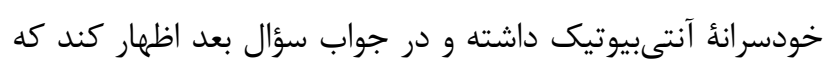

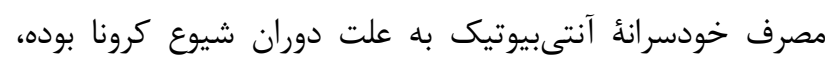

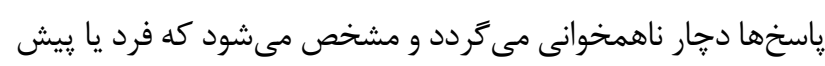

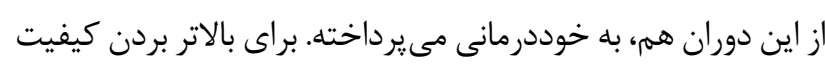

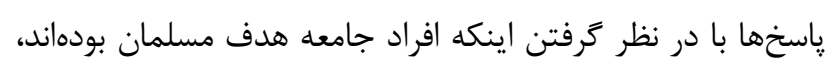

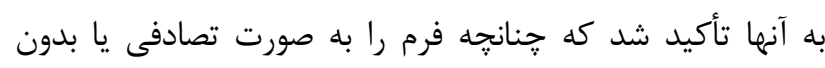

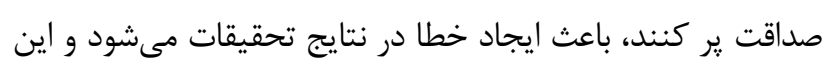

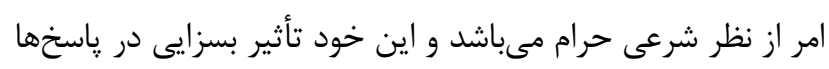

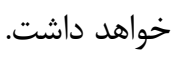

\section{بافتهها و بحث}

در طى • ا روز 191 نفر يرسشنامه را ير نمودند كه شامل

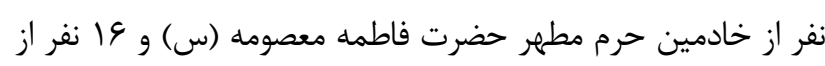

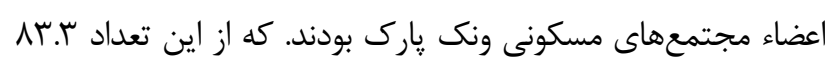

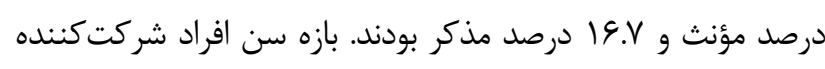

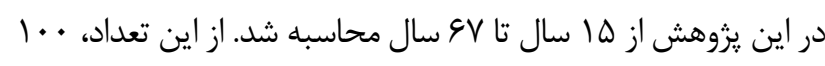




\section{Referance}

1. Getahun H, Smith I, Trivedi K, Paulina S, Balkhyb HH. Tackling antimicrobial resistance in the COVID-19 pandemic. Bull World Health Organ. 2020;98:442-A. [DOI:10.2471/BLT.20.268573] [PMID] [PMCID]

2. D'Costa VM, King CE, Kalan L, Morar M, Sung WW, Schwarz C, et al. Antibiotic resistance is ancient. Nature. 2011;477(7365):457-61. [DOI:10.1038/nature10388] [PMID]

3. Tavakooli R. Effect of important variables; economic, social and cultural on self-medication. Daneshvar Medicine. 2001;8(34):9-12.

4. Moghaddam Nia A. Self medication in cold among population above 15 years of age in Babol. Journal of Babol University of Medical Science. 2007;2(1):26-32.

5. Masoudi Alavi N, Izadi F, Ebadi A, Hajbagheri A. Self treatment experience in diabetes mellitus type 2. Iranian Journal of Endocrinology and Metabolism. 2009;10(6):581-8.

6. BAGHIANI MM, Ehrampoush M. Evaluation of attitude and practice of students of Yazd University of Medical Sciences to self-medication. 2006.

7. Greenhalgh T. Drug prescription and self-medication in India: an exploratory survey. Social science \& medicine. 1987;25(3):307-18. [DOI:10.1016/0277-9536(87)902334]

8. Patricia J, Neafsey R, Olga J, Surheil L. Self medication practice in spanish speaking older adults. Hispanic Health Care International. 2007;5(4):169-78. [DOI:10.1891/154041507783095795]

9. Shamsi M, Tajik R, Mohammadbegee A. Effect of education based on Health Belief Model on selfmedication in mothers referring to health centers of Arak. Journal of Arak University of Medical Sciences. 2009;12(3):57-66.

10. Almasdy D, Sharrif A. Self-Medication Practice with Nonprescription Medication among University Students: a review of the literature. Archives of Pharmacy Practice. 2011;2(3):95. 